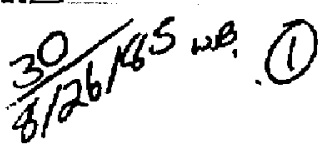

$$
\text { Bf } 125^{2-1} \quad I .22607
$$

UCID--20436

DE85 017148

MetallurgicaT Analysis

of a 304L Stainless Steel Canister

from the Spent Fuel Test--Climax

H. Heiss

R. A. Van Konynenburg

R. D. Mccright

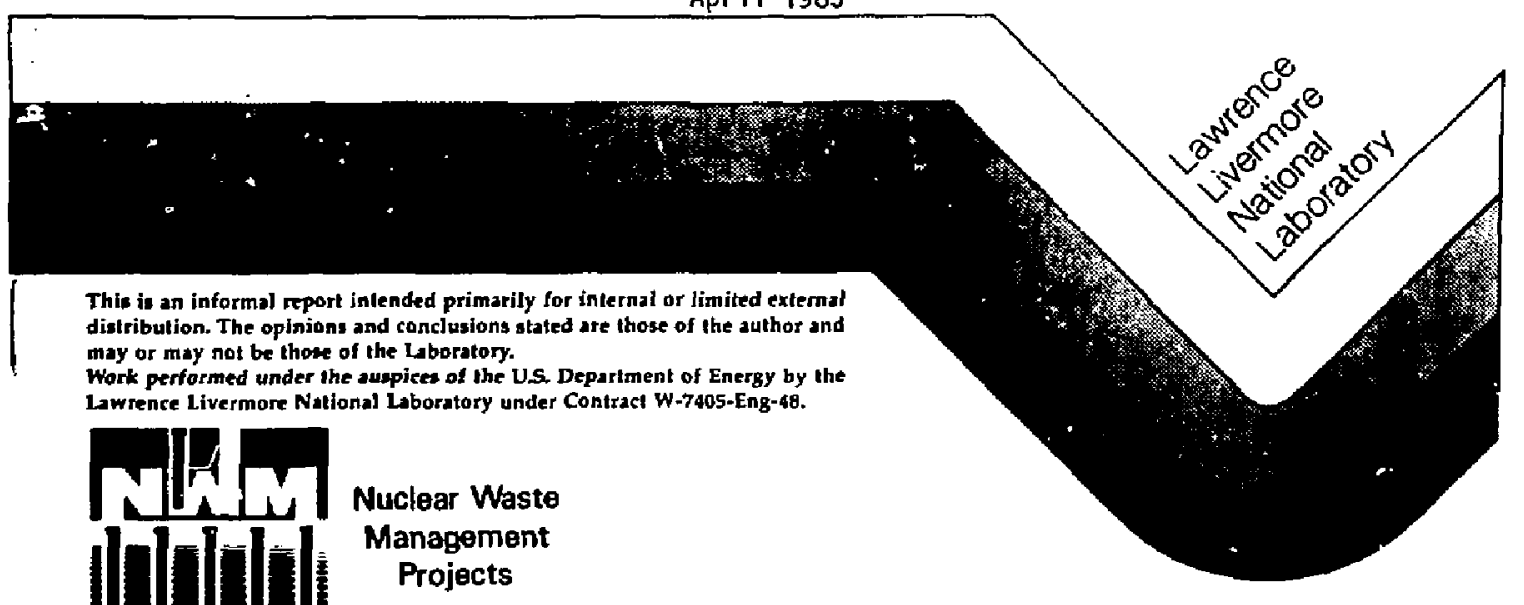

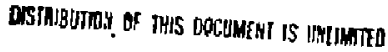




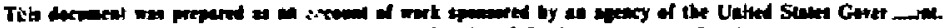

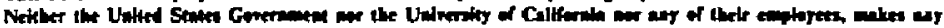

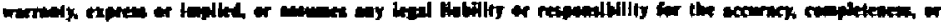

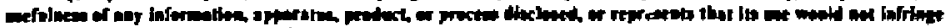

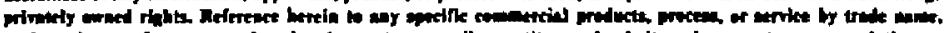

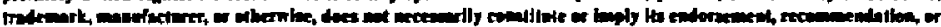

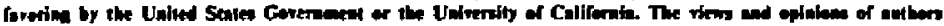

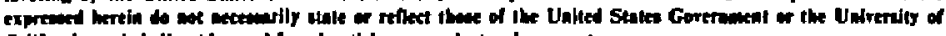

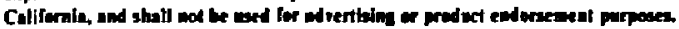

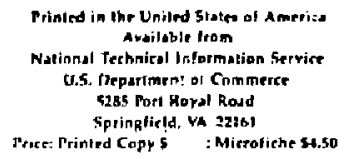

\begin{tabular}{|c|c|c|c|c|}
\hline rage Range & $\begin{array}{c}\text { Domestic } \\
\text { Price } \\
\end{array}$ & Page Range & & $\begin{array}{l}\text { mestic } \\
\text { Price }\end{array}$ \\
\hline 001-025 & 57.00 & $326-350$ & $\mathbf{s}$ & 26.50 \\
\hline $026-050$ & 8.50 & $351-375$ & & 28.00 \\
\hline $051-075$ & 10.00 & $376-400$ & & 29.50 \\
\hline $076-100$ & 11.50 & $401-426$ & & 31,00 \\
\hline $101-125$ & 13.00 & $427-450$ & & 3250 \\
\hline $126-150$ & 14.50 & $451-475$ & & 34.00 \\
\hline $151-175$ & 16.00 & $\$ 76-500$ & & 35.50 \\
\hline $176 \cdot 200$ & 17.50 & $501-525$ & & 37.00 \\
\hline $201-225$ & 19.00 & $526-550$ & & 38.50 \\
\hline $226-250$ & 20.50 & 551-575 & & 40.00 \\
\hline 251.275 & 22.00 & $576-600$ & & 41.50 \\
\hline $276-300$ & 23.50 & 601-up' & & \\
\hline $301-325$ & 25.00 & & & \\
\hline
\end{tabular}

'Add 1.50 for each additional 25 page increment, or portion there of from 601 pages up. 


\section{Metallurgical Analysis of a 304L Stainless Steel Canister from the Spent Fuel Test--Climax}

H. Weiss, R. A. Van Konynenburg, and R. D. McCright April 23, 1985

\section{ABSTRAC T}

Results of a metallurgical examination of a type $304 \mathrm{~L}$ stainless steel canister that had been used to store spent nuclear fuel in an underground granite formation for about three years are reported. No observable corrosion or cracking were found. The results are applied to waste packages in a potential high level nuclear waste repository in tuff.

Work performed under the auspices of the U.S. Department of Energy by th Lawrence Livermore National Laboratory under contract number W-7405-ENG-48. 
In April and May of 1980, Lawrence Livermore National Laboratory emplaced 11 spent nuclear-reactor fuel assemblies and six electrical heater assemblies ill the Climax stock quartz monzonite at the Neiada Test Site. Known as the Spent Fuel Test--Climax (SFT-C), the test was conducted as part of the Nevada Nuciear Waste Storage Investigations (NNWSI) for the U.S. Department of Energy.

The overall objective of the SFT-C was to evaluate the feasibility of safe and reliable short-term storage of spent fuel assemblies at a plausible repository depth in a typical granitic rock and to retrieve the fuel afterwards. An additional objective of the original concept was to evaluate the differences, if ariy, between the effects of real fuel storage and electrical simulation of the thermal output. (1)

While the SFT-C was underway, planning moved ahead on the selection of a site for the first permanent U.S. high level nuclear waste repository. One candidate 5 ite that was identified is located in tuff rock at Yucca Mountain, at the western edge of the Nevada Test Site. The tuff site is also part of the responsibility of the NNWSI project. As information about the expected environment of the waste packages in tuff became available, we noticed some similarities between the two sites with respect to the fluid media (air and water), the temperature ranges, the radiation levels, and the dissolved chemical species. As planning progressed, the canister material that had been used in the SFT-C (304L. stainless steel) was also selected as the reference material for the waste packages in the tuff repository. Because of the 300 to 1000 year period of containment required by the Nuclear Regulatory Commission for the repository, corrosion resistance emerged as the dominant property needed in this application. It occurred to us that we might be able to learn some useful information about the corrosion performance of our reference material in the tuff repository by examining its behavior in the climax facility. This report documents what was learned.

When we reviewed the history of the SFT-C canisters, the canister that

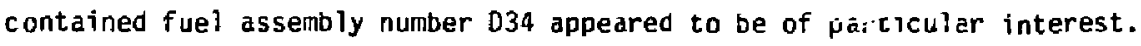
This canister had been located in $\mathrm{Cl}$ imax Emplacement Hole ${ }^{2}$ (CEH 1 ) where, as 
a result of a liner leak, the bottom part of the canister was unintentionally submerged in water for a period of at least eight months. For the remainder of the three-year period, its environment was irradiated moist air. We decided to examine this canister for evidence of corrosion.

\section{CANISTER AND LINER DESCRIPTION (2)}

The fuel assemblies used in the SFT-C were of Westinghouse pressurized water reactor (PWR) design. They had been removed from the core of the Turkey Point Unit \#3 reactor about $21 / 2$ years before their emplacement at the SFT-C. Each assembly consisted of a $15 \times 15$ square array of Zircaloy-4 clad fuel rods.

Each spent fuel assembly was inserted into a stainless steel canister, as shown in Fig. 1. The canister consisted of a canister body and a closure 1id. The main body of the canister was a standaro $356 \mathrm{~mm} 00,9.52 \mathrm{~mm}$ wall, Type $304 \mathrm{~L}$ stainless steel pipe $3.92 \mathrm{~m}$ long. A standard $9.52 \mathrm{~mm}$ wall, Type 304L stainless steel eliipsoidal end $c$ ap was welded to the bottom of this pipe. A cruciform-shaped fixture fabricated from $19 \mathrm{~mm}$ thick Type $304 \mathrm{~L}$ stainless steel was welded into the end $c$ ap. This fixture supported the fuel assembly and served as a loose-clearance keyway into which the fuel assembly bottom nozzle fitted.

The upper body of the canister consisted of a section of $356 \mathrm{~mm} 00,23.8$ $\operatorname{mim}$ wall. Typed $304 \mathrm{~L}$ stainless steel pipe, approximately $230 \mathrm{~mm}$ long. This section was welded to the top of the main body and containeo all the machined mating features for the closure 1 id. The $c$ anister body welds were made in accordance with Section IX of the ASME Boiler and Pressure Vessel Code and were inspected by dye penetrant. All external canister welds were made using Type $308 \mathrm{~L}$ stainless steel weld wire.

Welded to the inside of the canister body was a Type 304 stainless steel support sage to hold the fue' assembly, formed from standard angles tied together on four sides by thin plates at six elevations. This cage provided lateral support over the entire length of the fuel assembly, limiting its possible lateral movement to about $8 \mathrm{~mm}$. 
After each canister was fabricated and cleaned, che fuel assembly was inserted. The closure lid was screwed in and welded, and the canister was evacuated, backfilled with helium, and sealed.

The canisters were lowered into vertical holes drilied into the floor of the Climax facility, located $420 \mathrm{~m}$ below ground level and $1116 \mathrm{~m}$ above sea 1evel. The holes had been ined with carbon steel liners prior to insertion of tine canisters (see Fig. 2). These liners had been grouted in position at top and bottom. The liners had an 00 of $457 \mathrm{~mm}$ and a wall thickness of 6.35 m.r. The liners were about $4.9 \mathrm{ml}$ long, and were fabricated from two sections of carbon steei pipe. Six thermocouples were placed at various locations along both the liner wall and the outside surface of the canister.

\section{STORAGE HISTORY}

The canister containing fuel assembly 034 was emplaced on April 25, 1980. On August 17, 1982, the canister was removed and inspected for a period of 5.3 hours. It was then reinstalled into the liner and remained there until final remova 1 on March 3, 1983.

Thermocouple data from the canister midheight indicate a maximum temperature of between 135 and $140^{\circ} \mathrm{C}$ for a period of approximately two months. Of more significance, $F i g .3^{(3)}$ shows the themocouple data from near the bottom of the canister. It $c$ an be seen that tre canister temperature rose to a level near the boiling point of water for this elevation (about $96.5^{\circ} \mathrm{C}$ ) and remained there until a time corresponding to about 3.1 years out of the reactor core. At about 3.0 years out of care the thermocouple on the liner recorded an abrupt $r$ ise in temperature. It was noted that water was present outside the liner when the liner was emplaced. It is surmised that water had leaked through a crack in the liner early in the test and entered the annular region between the canister and liner as well as the region outside the liner. The rise in the liner temperature occurred when the water between the liner and the rock had completely departed, either by evaporation or percolation through the rack. This produced a poorer thermal conductance between them, because of the change in the primary thermal transport mechanism from conduction-convection to radiation, and allowed the decay heat from the 
canistier to raise the 1 iner temperature. The canister temperature did not rise when this occurred because water remained in the canister-ifiner annulus. This was possible because the crack in the liner weld had sealed, probably dise to precipitation of solute minerals. The boiling and refluxing of this water held the canister temperature nearly constant. The gradual rise in canister temperature was probably due to concentration of solute species by -istillation, which raised the boiling point of the solution. The thermal output decreased with time by nuclear decay until boiling ceased at about 3.1 years out-of-core. The water in the canister-liner annulus slowly evaporated through the gap around the shield plug (see Fig. 2). In support of this suggestion, it should be noted that water was observed on the ledge under tive concrete shield plug when it was lifted.

Upon removal of the canister and inspection of the components in August of 1982, it was observed that the interior of the liner was dry, thus conf irming that water was no longer present in the annulus between the liner and the canister at that time. Water level measurements in the annulus between the $l$ iner and the rock established that water was again present in this region. The presence of water in the outer annulus coupled with its absence from the inner annulus supports the hypothes is that the crack in the liner had sealed by this time. A sample of this water was collected for analysis.

After the storage period of the SFT-C was completed, the liner was removed and inspected. It was observed that the welds holding the bottom end cap onto the $l$ iner had been performed with shal low penetration and had cracked, thus providing a path for the water to enter the liner. (4) Upon inspection of the canister, we did not see any evidence of a water mark or stain on the stainless steel. However, a stain was observed on the inside of the liner.

During the three years of storage, the gamma ray dose rate at the mid-line of the canister outside surface $(5,6)$ decayed from a starting value of $1.9 \times$ $10^{4} \mathrm{rad} / \mathrm{hr}(53 \mathrm{mGy} / \mathrm{s})$ to a final value of $8.0 \times 10^{3} \mathrm{rad} / \mathrm{hr}(22 \mathrm{mGy} / \mathrm{s})$. The total dose during the three-year period was $3.2 \times 10^{8} \mathrm{rad}(3.2 \mathrm{MGy})$. A) 1 these values are given on a lithium fluoride basis. At the top and botton: ends of the canister the dose rates and dose are estimated to be about half as large as at the injd-line. 
In discussing the condition of the canisters, it is relevant to point out that an interesting observation was made on the corrosion of the liners: All eleven carbon steel liners that had contained spent fuel showed much more evidence of external corrosion near the top of the fueled section than those containing electrical simulators. At some locations, the depth of corrosion amounted to as much as $5 \mathrm{~mm}$. In all likelihood this resulted from the production of nitric acid and other oxidizing chemical species by the irradiation of moist air and their condensation onto the ccolest accessible regions of the liner, near the top of the fueled section.

The chemical composition of the water solution that was in contact with the canister can only be approximated, since it was not sampled directly. The water sample taken from the liner-rock annulus was analyzed by inductively-coupled plasma optical emission spectroscopy (ICP-OES) and ion chromatography (IC). The results are shown in Table 1 . For comparison, analyses are also shown for water from the two sampling locations in the Climax facility that were nearest hole $\mathrm{CEH}+1$, taken prior to spent fuel emplacentent, (7) and from well $\mathrm{3}-13$, near Yucca Mountain. (8) It can be seen that the $\mathrm{Climax}$ pre-emplacement water is relatively high in $\mathrm{Na}, \mathrm{Ca}$, $\mathrm{SO}_{4}^{-}, \mathrm{Cl}^{-}$, and $\mathrm{HCO}_{3}^{-}$. The water taken from the $\mathrm{CEH} 1$ liner-rock annulus is significantly frigher in $\mathrm{K}$ and lower in $\mathrm{Ca}, 50_{4}^{=}$, and $\mathrm{Cl}^{-}$. (Unfortunately, $\mathrm{HCO}_{3}^{-}$was not measured, but ionic balance would dictate a concentration in excess of $1300 \mathrm{mg} / \mathrm{L}$.) We do not current]y understand the details of the processes that led to these differences in composition. However, factors such as variation in equilibria with temperature, concentration by distillation, contact with the zinc-coated steel liner, interaction with the grout, radiolys is, and ion exchange with the rock probably contributed. It is possible that contamination by drilling detergent used in drilling the nearby access hole also occurred.

\section{METALLOGRAPHIC EXAMINATION}

In June of 1984, the canister was examined at the E-MAD farility by the authors. At that time, the canister had been cut into seven cylindrical pieces and the bottom dome section, as shown in Fig. 4 . All pieces were steam cleaned to remove any contamination and shipped to LLNL. Several areas were 
selected for further inspection; specifically, areas containing two different types of welds, samples for chemical analysis, and a "suspicious" area that appeared to be a corrosion pit.

It was determined that the canister was fabricated from longitudinally welded pipe, with both inside and outside welds, as shown in Fig. E. This weld appears to have been produced by an autogenous resistance-type process, based upon the large width of the fusion zone and the amount of upset in the center, unwelded region. The weld is sound with no fissures; hawever, one can find fauit with the lack of penetration through the wall.

The end cap, Fig. 6, was attached using a multipass, filler weld process. A chemical analysis of the weld material suggests that it was probably AISI 308-type material. The weld appears to be sound and functional. The base material was also analyzed and all the analytical results are shown in Tab]e II.

Metallographic examination of the "corrosion pit", Fig. 7 and 8 , shows that the surface damage was due to an ars strike. Higher magnification, Fig. 9. indicates no evidence of pitting attack or intergranular corrosion penetrating into the metal.

\section{APPLICATION TO WASTE PACKAGES FOR TUFF REPOSITORY}

Although the canister was subjected to only three years of storage, it is encouraging to note that the AISI 304L canister material suffered no observable corrosion or cracking. This observation is even more positive, considering that the 1 iner surrounding the canister containing assembly 034 leaked and provided a more hostile aqueous environment.

In applying this result to the waste packages for the tuff repository, one must examine the environmental parameters that are known to be important to corrosion. (9) These include the physical state of the corrosion medium (1 iquid or gaseous), the chemical nakeup of the medium, the temperature, the pressure, the $\mathrm{pH}$, the redox potential, the flow rate, and the radiation dose rate. 
In the tuff repository, we expect an eivtronment of steam and air initiaily, followed by some condensation after cooling below $95^{\circ} \mathrm{C}$. Inundation with water is thought to be very unlikely. The chemical composition of groundwater in the tuff site is thought to be we1l represented by the $\mathrm{J}-13$ well water composition, shown in Table 1 . The temperature is expected to range from rock ambient to a maxinum of $270^{\circ} \mathrm{C}$. The pressure will be atmospheric for an altitude of $880 \mathrm{~m}$ above sea level. The $\mathrm{pH}$ is expected to remain near neutral or slightly alkaline for water in contact with the rock. In regions of the package surfaces not in contact or in liquid diffusive communication with the rock, it is possible that lower pH values could arise, because of radiolytic fixation of nitrogen in the gas phase, followed by condensation and dissolution in water films on surfaces, producing nitric acid,

The redox conditions in the tuff repository will be oxidizing because of the presence of air and radiation. The flow rate is expected to be quite sma11, because the water infiltration rate is estimated to be less than $1 \mathrm{~mm} /$ year. THe gamma ray dose rate at the waste packages is expected to range up to $10^{5} \mathrm{rad} / \mathrm{hr}$ as a maximum, with older waste having lower levels.

In comparing these conditions to those in the SFT-C, one finds several similarities. First of all, we are Jealing with Type $304 \mathrm{l}$ stainiess steel in both cases. If hole liners are needed for retrievability in the tuff repository, carbon steel would likeiy be selected, as in the SFT-C. During most of the period in the SFT-C, the canister surface was below the boiling point and could maintain a water $f i l m$, which we expect will be the most corrosive condition in the tuff repository. The water in SFT-C was more concentrated in total dissolved species, particularly in chloride, which is known to be detrimental to stainless steels. Although the temperatures in SFT-C were below the maximum for the repository, it is expected that the lower tamperatures will represent more severe corrosion conditions, as mentioned above. In any case, the tuff waste packages will eventually cool into this regime (see 0'Neal et al. for calculated waste package thermal history). (10) The pressure is similar in the two cases, being atmospneric. The pH conditions are also comparable. (7) Both facilities have an oxidizing environinent. The flow rate at the canister in the SFT-C was necessarily fairly low because the water came through a cracked weld. The radiation 
levels are in the same regime for older fuel or defense waste in the repository. All in a11, it appears that there are enough similarities that a usef 11 comparison $c$ an be made. Probably the largest differences are in the chemical makeup of the water, but the $c l$ imax water appears to be more aggressive from a corrosion standpoint.

In conclusion, although conditions are not identical in the two facilities and only three years of exposure were performed, the excellent performance of Type 304L stainless steel in the SFT-C speaks well for its prospects in the tuff rooository. Certainly if significant corrosion had been observed, we would have had great cause for pause, and it is reassuring that none was. 


\section{REERENCES}

1. L. D. Ramspott et al., "Jechnical Concept for a Test of Geologic Srorage of Spent Reactor Fuel in tile Climax Granite, Neyada Test Site," UCRL-52796, Lawrence Livermore National Laboratory, Livermore, CA, (1979).

2. U. S. Department oi - vergy - Nevada Operations Office, "Safety Assessment Document for the Spent Reactor fuel Geologic Storage Test in the Climax Granite Stock at the Nevada Test Site," NV0-210, (Jinuary 1980).

3. W. C. Patrick et al., "Spent Fuel Test--Climax: Technical Measurements Inter im Report, Fiscal Year 1981," UCRL-53294, Lawrence Livermore National Lahoratory, Livermore, Cí, (1982).

4. W. C. Patrick et al., "Spent Fuel Test--Climax: Technical Measurements Interin Report, Fiscal Year 1983," UCRL-53294-83, Lawrence Livermore Nationa i Laboratory, Livermore, CA, (1942).

5. T. P. Wilcox and R. A. Van Konynenburg, "Radiation Dose Calculatiors for Emplacement Holes in the Cl iriax Granite, Nevada Test Site, "UCRL -53159 , Lawrence Livermore National Laboratory, Livermore, CA, (1981).

6. R. A. Van Koryierburg, "Radiation Dose in Granite Around Emplacement Holes in the Spent Fuel Test--C'Timax (Final Report), UCRL-53580, Lawrence Livermore National Laboratory, Livermore, CA, (1984).

7. D. Isherwood, J. Harrar, and E. Raber, "Characterization of Climax Granite Ground Water," UCRL-53309, Lawrence Livermore National Laboratory, Livermore, $C A,(1992)$.

8. V. M. Oversby, "Reaction of the Topopah Spring Tuff with J-13 hater at $120^{\circ} \mathrm{C}$," UCRL-53574, Lawrence Livermore National Laboratory, Livermore, CA. (1984). 
9. R. A. Van Konynenburg and R. D. McCright, "Corrosion Performance of Metals and Alloys in a Tuff Geachemical Environment," UCRL-91740, to be published in Proc. of the Waste Management 'B5 Conference, University of Arizona, Tucson, AZ, (1985).

10. W. C. O'Neal et al., "Preclosure Analys is of Conceptual Waste Package Designs for a Nuclear Waste Repository in Tuff," UCRL-53595, Lawrence Livermore National Laboratory, Livermore, CA, (1984). 
TABLE I

Comparison of Water Analyses from Climax Facility and Well J-13 (nkg/L)

\begin{tabular}{|c|c|c|c|c|}
\hline \multirow{3}{*}{ Species } & \multicolumn{3}{|c|}{ Cl iiflax Facility } & \multirow[t]{2}{*}{ Kell $1-13^{(8)}$} \\
\hline & $\mathrm{NH}-0 \mathrm{f}(7)$ & $\mathrm{UG}_{\mathrm{N}} \mathrm{2}^{(7)}$ & CEH\#I & \\
\hline & \multicolumn{2}{|c|}{ (0.4 un filtered) } & (0.45 um filtered) & $(0.1 \mu \mathrm{m}$ filtered $)$ \\
\hline $\mathrm{Na}$ & 229 & 214. & 273. & $43.9+1.19$ \\
\hline $\mathrm{Ca}$ & 240 . & 114. & 16.0 & $12.5 \pm 0.77$ \\
\hline $\mathrm{SiO}_{2}$ & 22.5 & 23.9 & 7.4 & $57.7 \pm 1.0$ \\
\hline$K$ & 3.8 & 4.7 & 538. & $5.11 \pm 0.32$ \\
\hline $\mathrm{Mg}$ & 4.8 & 1.5 & $<0.008$ & $1.92 \pm 0.06$ \\
\hline$S r$ & 7.9 & 4.2 & 0.69 & 0.054 \\
\hline$u$ & 18.5 & $<0.1$ & $<0.076$ & $<0.084$ \\
\hline Al & 0.05 & 0.02 & 1.67 & $0.012 \pm 0.010$ \\
\hline $\mathrm{Fe}$ & $0.5^{\mathrm{a}}$ & $0.8^{a}$ & 0.004 & $0.006 \pm 0.005$ \\
\hline $2 n$ & $0.03^{\mathrm{a}}$ & $0.03^{\mathrm{a}}$ & 3.2 & $<0.008$ \\
\hline$M n$ & 0.008 & 0.05 & $<0.001$ & $<0,0005$ \\
\hline $\mathrm{Li}$ & 0.17 & 0.17 & 0.40 & 0.042 \\
\hline Mo & 0.22 & 0.09 & 0.029 & 0.013 \\
\hline$T \mathbf{j}$ & 0.02 & $<0.002$ & $<0.002$ & N.D. \\
\hline B & N.D. ${ }^{b}$ & N.D. & 0.047 & $0.128 \pm 0.008$ \\
\hline $\mathrm{PO}_{4}$ & 0.5 & $<0.3$ & N.O. & $<.0 .3$ \\
\hline $\mathrm{SO}_{4}$ & 850. & 480. & 193. & $18.7 \pm 0.47$ \\
\hline $\mathrm{Cl}^{4}$ & 160. & 70. & 30. & $6.9 \pm 0.21$ \\
\hline $\mathrm{HCO}_{3}$ & 65. & 165. & N.M. ${ }^{C}(1322)^{d}$ & $136 . \pm 8.1$ \\
\hline 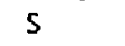 & N.D. & 3.0 & N.D. & N.D. \\
\hline $\mathbf{F}$ & N.D. & 1.4 & 3.8 & $2.2 \pm 0.32$ \\
\hline $\mathrm{NO}_{3}$ & N.D. & N.D. & 2.5 & $9.6 \pm 3.63$ \\
\hline TOTAL & 1603. & 1083. & $(2386)^{d}$ & 295 \\
\hline
\end{tabular}

a. Samples known to be contaminated from drill bit and wire mesh

b. N.D. - N Not detected

c. N.M. -- Not meüsured

d. Calculated from ionic balance 
TABLE II

Chemical Analysis of Canister Materials

308 filler

Autogenous Weld

$0.017 \%$

1.19

0.021

0.014

0.49

18.24

9.67

0.73

0.42

Remạinder
Base Material

$0.018 \%$

1.89

0.020

0.011

0.54

18.46

9.05

0.50

0.25

Remainder 


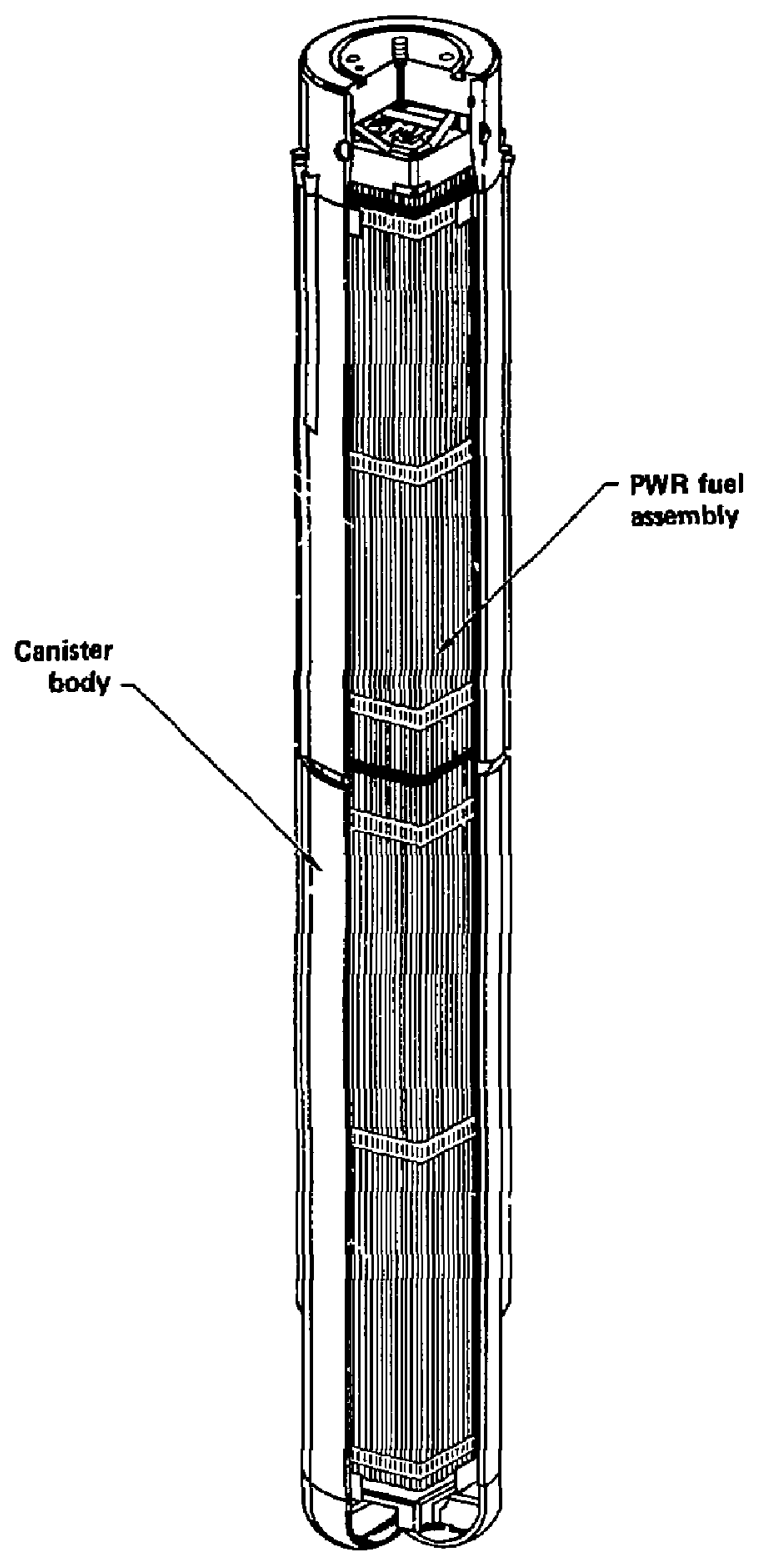

Fig, 1 Spent fuel canister assembly 


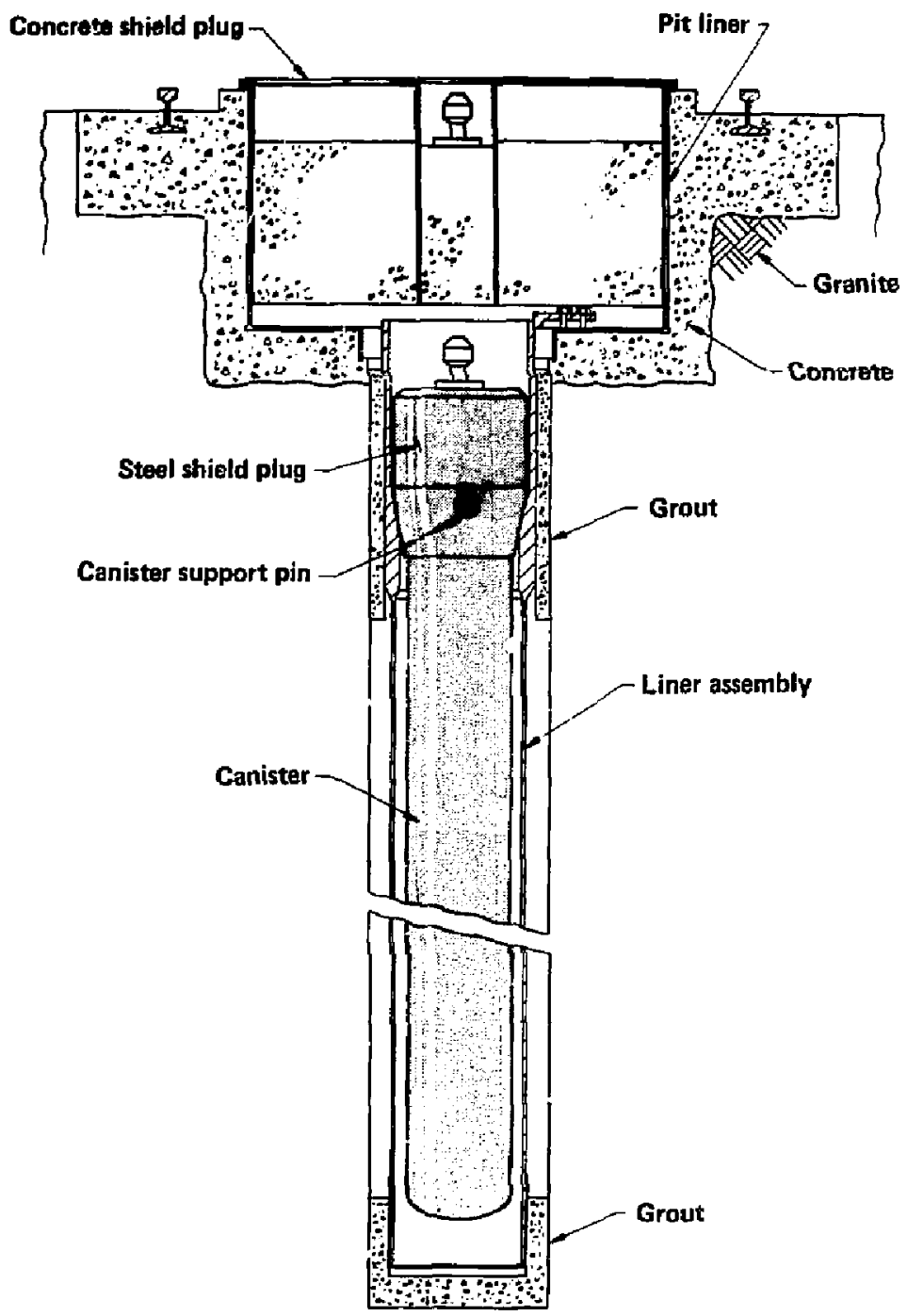

Fig. 2 Drawing of emplacement of liner and canister in repository. 


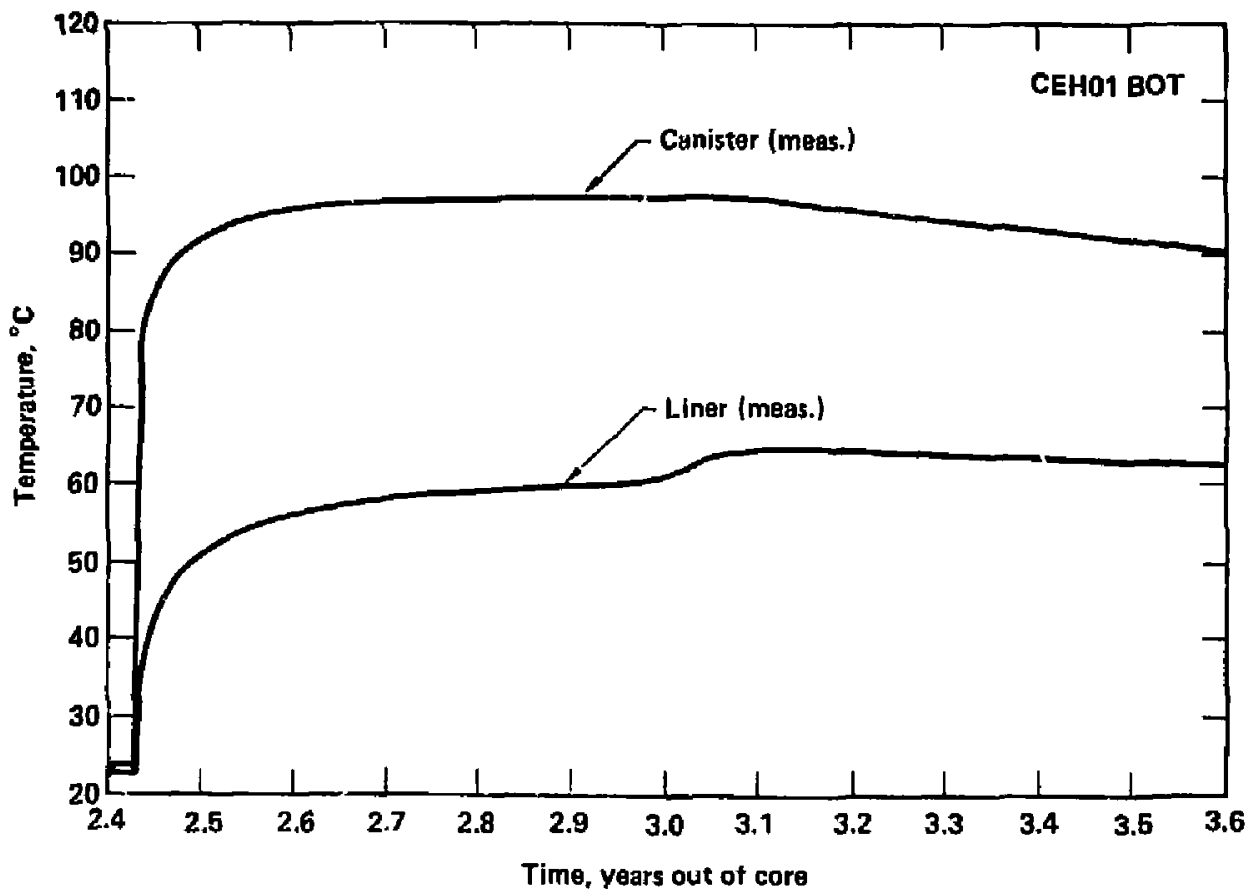

Fig. 3 Temperature inistories of the canister and boreholy tiner locatad in CEHO1. Note the break in the trends of the curves at about 3.0 YOC which result from water being boiled out of the Canister-liner annulus. 

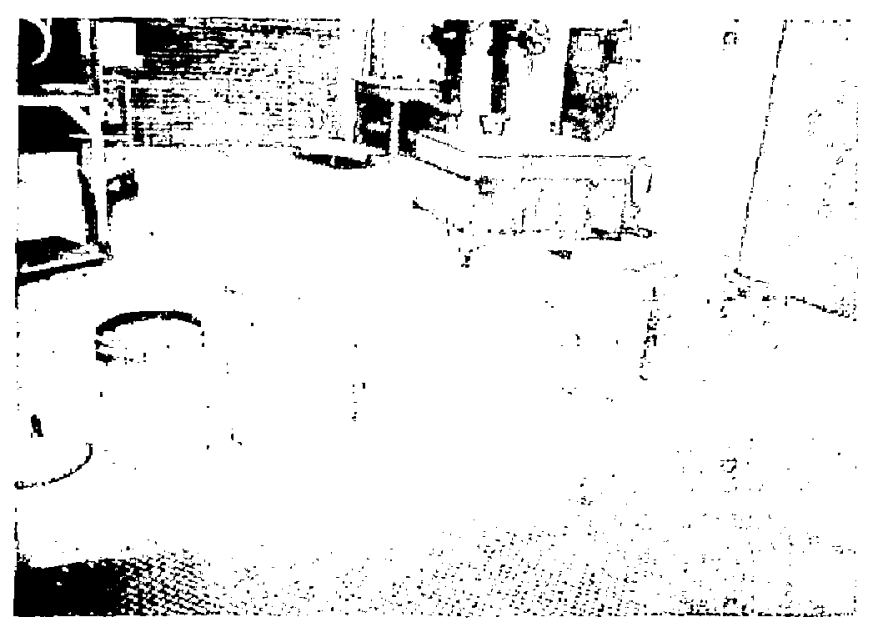

Fig. 4 Sectioned canistex from the D-34 fuel assembly emplaced in hole \#1. Sections labeled A (top) through G (bottom!.

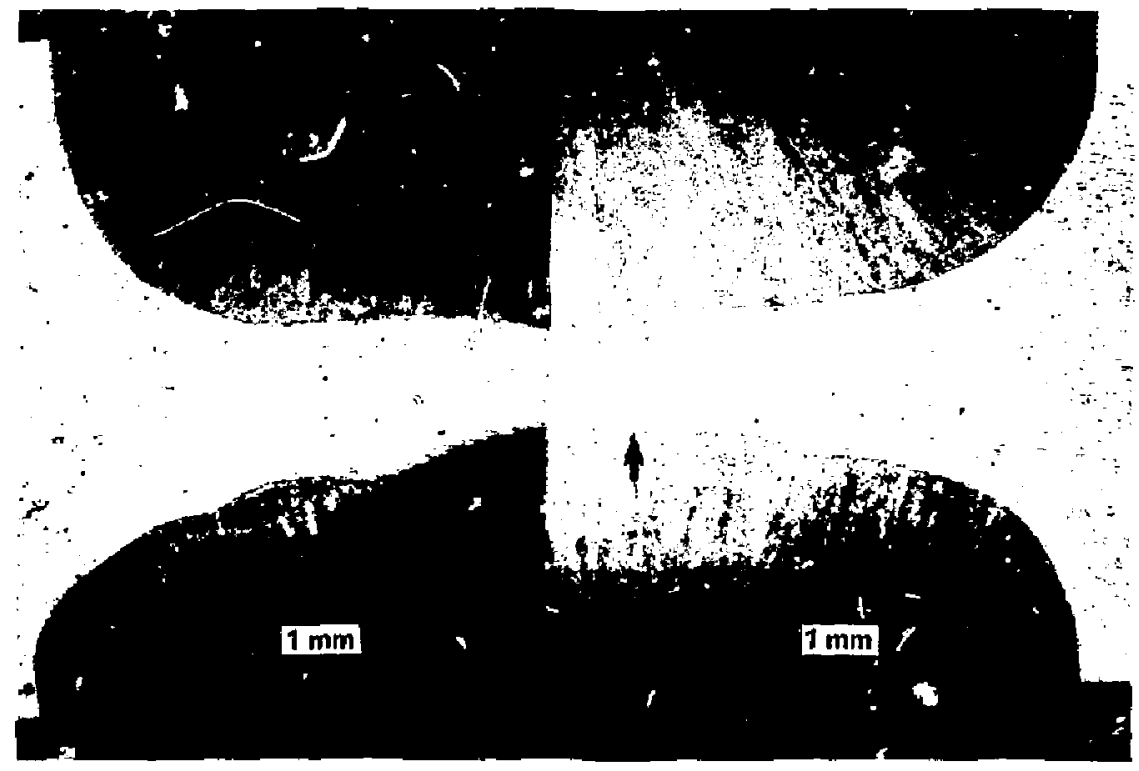

Fig. 5 Autoganous assembly longitudinal weld on canister body. showing incomplste weld penetration and high deformation area (at arrow). 


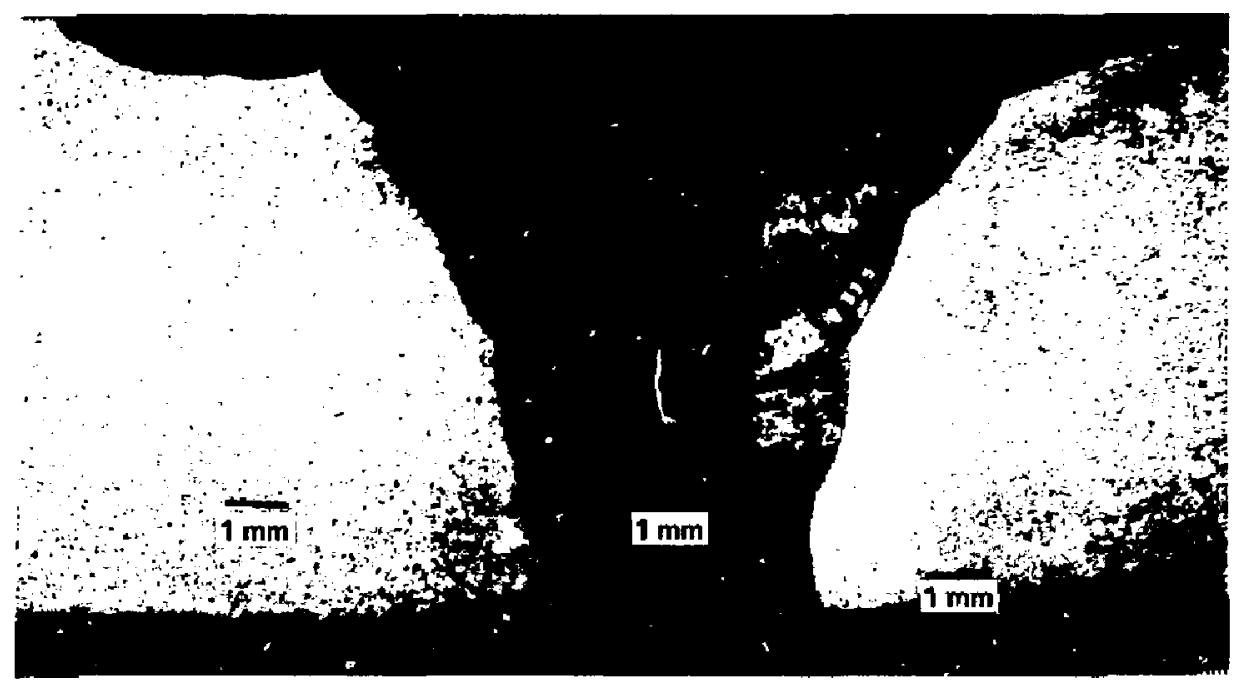

Fig. 6 Bottom circumferential weld section showing multipass filler wire process.

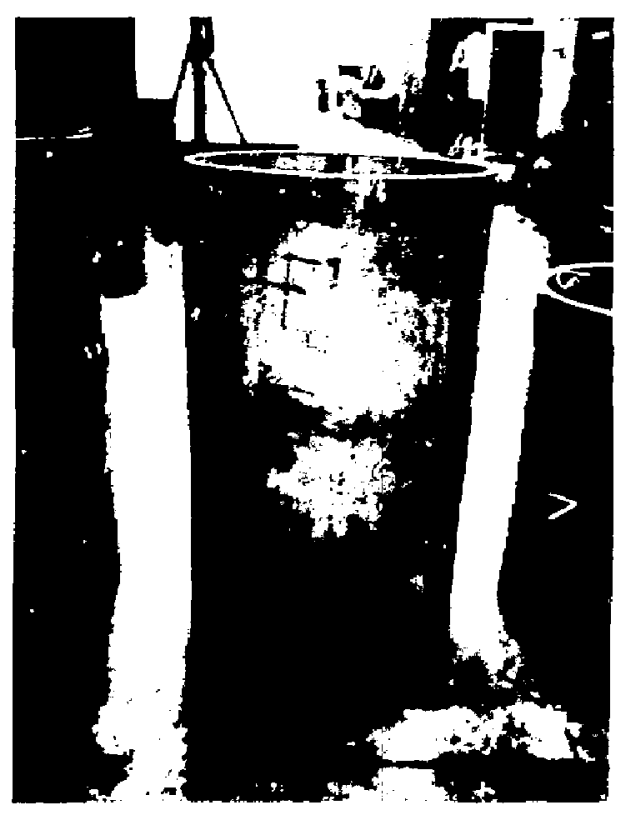

Fig. 7 Suspicious "corrosion" pit observed about four feet from bottom end cap. Analysis revealed this to be a welding arc strike. 


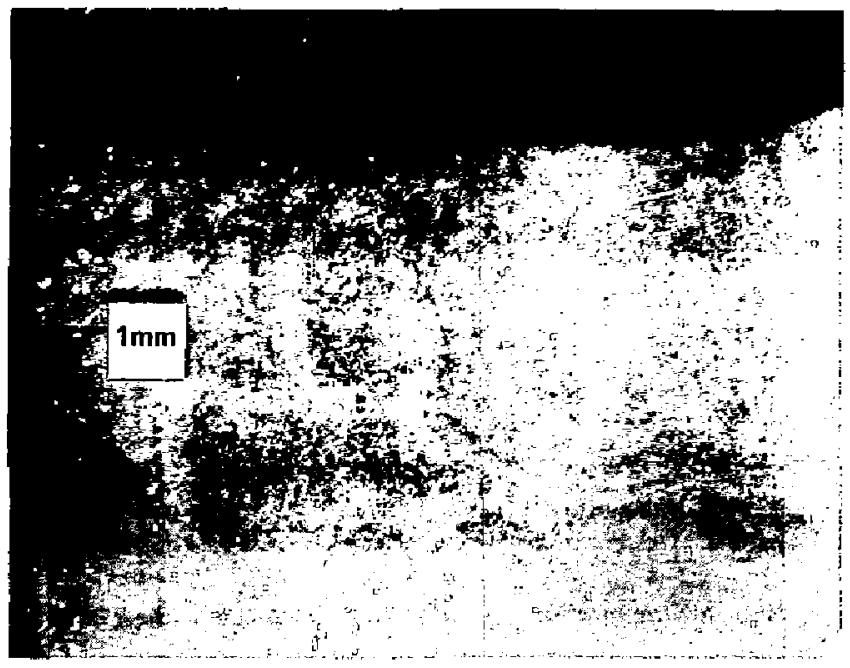

Fig. 8 Suspicious "corrosion" pit from section F of canister.

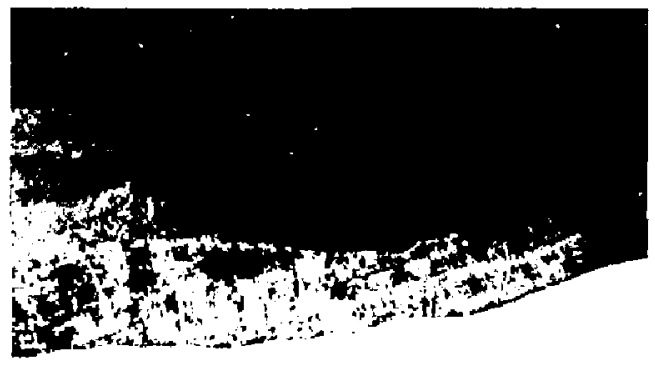

$\overline{200 \mu \mathrm{m}}$

Fig. 9 Suspicious "corrosion" pit at higher inagnification. No locelized corrosion penotration observed. 